\title{
Kanban in Apparel Manufacturing: A Case Study
}

\author{
RMVS Ratnayake, WDG Lanarolle, RMDT Ratnayake
}

\begin{abstract}
Pull system and Kanban are effective lean manufacturing tools. Though many companies in various manufacturing fields have successfully implemented pull manufacturing using Kanban systems, such studies in apparel manufacturing are rarely found. Kanban system was implemented in an apparel manufacturing company, which had implemented some of the lean manufacturing tools. The apparel manufacturing line was identified in four different sub sections and separate Kanbans were used in each sub section. The system was evaluated using two parameters: the number of Kanban cards in each point; the production output. Correct number of Kanban cards were found at all the time of the monitoring period of two weeks-the production efficiency has increased by $22 \%$.

Keywords: Pull system, Kanban system, Inventory fluctuation, smooth flow
\end{abstract}

\section{INTRODUCTION}

$\mathrm{P}_{\mathrm{u}}$ ull manufacturing is a lean manufacturing methodology that controls production from the end of the process [1]. Pull system operates as a backward motion- the products are produced when there is an order from the customer [2] delivers parts at each work station as per the production sequence from the finished goods towards upstream operations [3]. Pull system controls the flow of resources in a production process by replacing only what has been consumed, and at the same rate the finished or semi-finished goods are consumed [4]. Pull System smooths the flow of Work In Progress (WIP) [1], [3].

Pull system supports to avoid large inventories by making the production immediately and delivering to the internal or external customers. As the semi-finished goods are running as single pieces or as small batches, the defects are immediately visible, hence quick decisions can be made to solve any quality defects [2]. An effective pull system creates numerous benefits in terms of cost, quality, on time delivery and employee morale to an organization since it minimizes overproduction and excess inventory, hence reduce inventory, hence reduce the storing and handling costs [5], [2]. Heizer and Render [6] state that a company never achieves a low-cost strategy without good inventory

Manuscript received on June 20, 2021

Revised Manuscript received on June 25, 2021.

Manuscript published on June 30, 2021.

* Corresponding Author

RMVS Ratnayake*, Department of Textile \& Apparel Engineering, University of Moratuwa, Katubedda, Sri Lanka. Email: vijithar@uom.lk

WDG Lanarolle, Department of Textile \& Apparel Engineering,

University of Moratuwa, Katubedda, Sri Lanka. Email: wilath@uom.lk

RMDT Ratnayake, Industrial Systems Engineering, Asian Institute of Technology, Bangkok, Thailand. Email: dhanika.1004@gmail.com

(c) The Authors. Published by Blue Eyes Intelligence Engineering and Sciences Publication (BEIESP). This is an open access article under the CC BY-NC-ND license (http://creativecommons.org/licenses/by-nc-nd/4.0/) management. Toyota's management employed the pull system for over many years to earn remarkable and consistent profits, and capitalized the market over Volkswagen, Daimler, Ford and GM combined. Wal-Mart is another example of a company that used the pull system strategically and improved its efficiency [1].

Toyota practiced 'Kanban' system to control the inventory in its pull system [7] - [11]. 'Kanban' is a combination of two Japanese words 'Kahn', meaning a card and 'bahn' meaning a signal. Kanban means a card carrying a signal [3]. It is a visual indication to show the requirement of parts [2], [12]. Kanban is a card-based control system to convey instructions not to produce until needed [8], [12].

The objective of Kanban is to minimize the inventory of the work in progress (WIP) and the total cost of inventory [1], [13], [14].): it is an effective inventory management system.

Kanban can control the levels of the inventories in the system, to regulate production. When a buffer reaches its planned maximum level, the operator or the machine is instructed to stop producing the next piece [10]. Further, it maintains inventory levels by sending a signal to produce and to deliver a new consignment indicating that the material has been consumed [7]. By controlling the release of inventories into the system it achieves smoother production flow' with a steadier, more predictable output by reducing fluctuations [1], [14].

Implementation of Kanban involves six rules: do not pass defects-if defects found-stop the whole line to fix the defects; signals from following process goes to preceding process to withdraw parts; quantity of parts produced must be equal to the quantity of parts withdrawn by following process; parts must not be produced or conveyed when there is no Kanban; Kanban must be attached to actual parts- the number on the Kanban must agree with the number of actual parts [9], [10].

Kanban system is a very effective tool to improve the productivity-: it optimizes the process; reduce idle time of the process; makes the process flexible for any proposes; reduce wastage; continuous deliveries to costumer, and increases efficiency of the plant [15]. Moreover, it improves the quality, reduces cost, reduces the lead time and increases the flexibility. Among many companies implemented Kanban methodology, Toyota has made remarkable achievements in all these indicators [2], [3], [5].

Though, many industries have successfully implemented the pull system and Kanban systems, not many are available in the area of apparel manufacturing. This paper presents the Kanban system implemented at an apparel manufacturingthe selected company has implemented the lean manufacturing techniques such as 5S, Setup reduction, total productive maintenance (TPM) and total quality management (TQM).

Published By:

Blue Eyes Intelligence Engineering and Sciences Publication 1 (C) Copyright: All rights reserved.

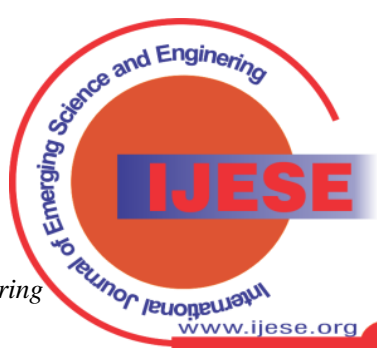




\section{METHODOLOGY}

\section{A. Introduction of the Production Line}

The selected factory produces men's wear apparels in 20 production lines. The management of the factory agreed to implement pull system through the Kanban tool as they have observed high WIP fluctuations in; all production lines. The management of the factory recommended to use a production line that was producing men's short-this line had comparatively high WIP fluctuation and the output was below the expected production.

The operation breakdown of the men's short contained 69 operations-the number of operators assigned to the line was 35. Almost all the operators were well trained, multi-skilled operators. As per the skill inventory report, skills of all the operators were more than $90 \%$. The work-study department had made a balancing chart and the production line followed it. Cutting section issues the cut bundles when the production line requested. A cut bundle contained 70 pieces. The factory uses their own time database to calculate the standard times of the products. According to that the standard time of a men's short was 33.61 minutes. Expected production in an 8 hours working day from this line was 500 pieces.

Initially, WIP of each operation were counted in the production line hourly- for 6 days. The average total WIP of the line was 426 and the WIPs of the operations were varied from 0 to 15. Also the average production output of this line for these 6 days were 424 pieces.

\section{B. Designing the Kanban System}

When designing a Kanban system the optimal number of Kanbans should be calculated, and a mechanism to extract the Kanban cards should be established [11], [15], [16]. The flow of the Kanban should be designed as per the operations flow of the production line [4]. All required manufacturing data to determine the number of Kanban cards and its flow was collected from the manufacturing line itself.

All input operation/s and output operation/s of each operation and the machine used in each operation were studied. It was decided to maintain 4 pieces bundles. A 4 pieces bundle was considered as 1 Kanban. Depending on the operations and the required parts, 1 Kanban may contains different parts. Required cut parts are delivered to the respective input operation by a line issuer with 4 pieces (I bundle) at a time. 18]:

The number of Kanbans was calculated as follows [17],

$$
\begin{gathered}
\text { Number of Kanbans } \\
=(\text { Demand } \times \text { Lead time }) \\
(1+\text { Safety stock }) / \text { Container size }
\end{gathered}
$$

As the lead time (production time) per garment is 33.61 minutes, the production time for 4 pieces is 134.44 minutes. The expected daily production (demand) is 500 pieces. Therefore, the expected production during the lead time is 140.04 pieces. As 4 pieces bundles were maintained, the additional 3 pieces contained in the bundle can be considered as the safety stock. The number of Kanban to be maintained in the line was 35 . There are 35 operators in the line-it required to maintain 1 Kanban with each operator.

The daily demand was 500 . The available time to produce 500 pieces (125 Kanbans) was 28,800 seconds. Therefore, the Takt time is 0.96 minutes-Takt time is the available time to produce single piece of the demand [20]. Thus, each
Kanban should be completed by the line in 3.84 minutes.

As per Japanese Management Association [19], if a Kanban system is implemented with large number of Kanbans it is unexpected to have a higher accuracy- when the number of Kanbans are smaller, more accurate results can be obtained. In order to obtain the more effective outcome it was decided to split the production line into several well defined sections so that the operators can work in their particular section. Considering the sequence of operations and the parts of the garment, initially 3 sections were identified as front operations, back operations the assembly operations. Standard times of the operations of these sections were 7.04 minutes, 10.59 minutes and 15.98 minutes respectively. The number of Kanbans to each section was allocated based on the standard time of the respective section. The number of Kanbans allocated to front operations, back operations and assembly operations sections were 7, 11 and 17 respectively. Since the assembly section has the higher number of Kanban, this section was divided into 2 sub sections: Assembly 1 and assembly 2 when assigning the Kanbans. Total standard time of the operations in assembly section 1 was 9.09 minutes and in assembly section 2 was 6.89 minutes. The number of Kanbans allocated to assembly sections 1 and 2 are respectively 10 and 7 .

The standard times assigned to each operation was taken from the work-study department. The procedure of implementing the Kanban system is described below using the front operation section. Table I shows the operations of the front operations and their input \& output operations with the standard time of operations and the machines used for each of the operations.

Also for the successful implementation of Kanban system all the employees in the selected production line were aware on the Kanban system and specially the six rules of Kanban. Thereafter trained them how to follow the rules and

\begin{tabular}{|c|c|c|c|c|}
\hline 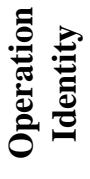 & & 范 & 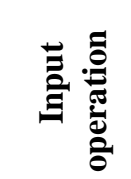 & $\sum_{\infty}^{Z}$ \\
\hline$A_{f}$ & $\begin{array}{l}\text { Facing attach } \\
\text { on front } \\
\text { pocket bag }\end{array}$ & $\mathrm{L} / \mathrm{S}$ & $\begin{array}{l}\text { Cutting } \\
\text { section }\end{array}$ & 0.82 \\
\hline $\mathrm{B}_{\mathrm{f}}$ & $\begin{array}{l}\text { Close pocket } \\
\text { bag }\end{array}$ & $4 \mathrm{O} / \mathrm{L}$ & $\mathrm{A}_{\mathrm{f}}$ & 0.58 \\
\hline $\mathrm{C}_{\mathrm{f}}$ & $\begin{array}{l}\text { Turn \& } \\
\text { outline } \\
\text { pocket bag }\end{array}$ & $\mathrm{L} / \mathrm{S}$ & $\mathrm{B}_{\mathrm{f}}$ & 0.60 \\
\hline $\mathrm{D}_{\mathrm{f}}$ & $\begin{array}{l}\text { Outline fly } \\
\text { hem }\end{array}$ & $\mathrm{L} / \mathrm{S}$ & $\begin{array}{l}\text { Cutting } \\
\text { section }\end{array}$ & 0.10 \\
\hline $\mathrm{E}_{\mathrm{f}}$ & $\begin{array}{l}\text { Attach } \\
\text { zipper to the } \\
\text { fly }\end{array}$ & $\begin{array}{l}\text { L/S, } \\
\text { zipper } \\
\text { foot }\end{array}$ & $\begin{array}{r}D_{\mathrm{f}} \& \\
\text { Stores }\end{array}$ & 0.40 \\
\hline
\end{tabular}
monitored their work.

Table- I: Details of the front section operations

Published By:

Blue Eyes Intelligence Engineering and Sciences Publication 


\begin{tabular}{|c|l|c|c|c|}
\hline $\mathrm{F}_{\mathrm{f}}$ & $\begin{array}{l}\text { O/L front } \\
\text { rises }\end{array}$ & $3 \mathrm{O} / \mathrm{L}$ & $\begin{array}{c}\text { Cutting } \\
\text { section }\end{array}$ & 0.22 \\
\hline $\mathrm{G}_{\mathrm{f}}$ & $\begin{array}{l}\text { Attach fly to } \\
\text { front }\end{array}$ & $\mathrm{L} / \mathrm{S}$ & $\mathrm{E}_{\mathrm{f}} \& \mathrm{~F}_{\mathrm{f}}$ & 0.26 \\
\hline $\mathrm{H}_{\mathrm{f}}$ & $\begin{array}{l}\text { Tack waist } \\
\text { band pieces } \\
\text { together }\end{array}$ & $\mathrm{L} / \mathrm{S}$ & $\begin{array}{c}\text { Cutting } \\
\text { section }\end{array}$ & 0.24 \\
\hline $\mathrm{I}_{\mathrm{f}}$ & $\begin{array}{l}\text { Sew waist } \\
\text { band Kansai } \\
\text { stitch }\end{array}$ & Kansai & $\mathrm{H}_{\mathrm{f}}$ & 0.24 \\
\hline $\mathrm{J}_{\mathrm{f}}$ & $\begin{array}{l}\text { Iron waist } \\
\text { band hem }\end{array}$ & Iron & $\mathrm{I}_{\mathrm{f}}$ & 0.30 \\
\hline $\mathrm{K}_{\mathrm{f}}$ & $\begin{array}{l}\text { Tack labels } \\
\text { on waist band }\end{array}$ & $\mathrm{L} / \mathrm{S}$ & $\begin{array}{c}\mathrm{J}_{\mathrm{f}} \& \\
\text { Stores }\end{array}$ & 0.28 \\
\hline $\mathrm{L}_{\mathrm{f}}$ & $\begin{array}{l}\text { Pocket bag } \\
\text { attach on } \\
\text { front }\end{array}$ & $2 \mathrm{~L} / \mathrm{S}$ & $\mathrm{C}_{\mathrm{f}} \& \mathrm{G}_{\mathrm{f}}$ & 0.58 \\
\hline $\mathrm{M}_{\mathrm{f}}$ & $\begin{array}{l}\text { Tack pocket } \\
\text { bag on side \& } \\
\text { waist }\end{array}$ & $\mathrm{L} / \mathrm{S}$ & $\mathrm{L}_{\mathrm{f}}$ & 0.38 \\
\hline $\mathrm{N}_{\mathrm{f}}$ & $\begin{array}{l}\text { Tack pocket } \\
\text { mouth top }\end{array}$ & $\mathrm{L} / \mathrm{S}$ & $\mathrm{M}_{\mathrm{f}}$ & 0.14 \\
\hline $\mathrm{O}_{\mathrm{f}}$ & $\begin{array}{l}\text { Attach WB } \\
\text { to fly corner }\end{array}$ & $\mathrm{L} / \mathrm{S}$ & $\mathrm{N}_{\mathrm{f}} \& \mathrm{~K}_{\mathrm{f}}$ & 0.21 \\
\hline $\mathrm{P}_{\mathrm{f}}$ & $\begin{array}{l}\text { Turn WB } \\
\text { corner of fly } \\
\text { side }\end{array}$ & Table & $\mathrm{O}_{\mathrm{f}}$ & 0.10 \\
\hline $\mathrm{Q}_{\mathrm{f}}$ & $\begin{array}{l}\text { Sew fly edge } \\
\text { stitch }\end{array}$ & $\mathrm{L} / \mathrm{S}$ & $\mathrm{P}_{\mathrm{f}}$ & 0.11 \\
\hline $\mathrm{R}_{\mathrm{f}}$ & $\begin{array}{l}\text { Sew fly J } \\
\text { stitch }\end{array}$ & $\mathrm{L} / \mathrm{S}$ & $\mathrm{Q}_{\mathrm{f}}$ & 0.32 \\
\hline $\mathrm{S}_{\mathrm{f}}$ & $\begin{array}{l}\text { Tack and } \\
\text { turn fly box }\end{array}$ & $\mathrm{L} / \mathrm{S}$ & $\begin{array}{c}\text { Cutting } \\
\text { section }\end{array}$ & 0.22 \\
\hline
\end{tabular}

\begin{tabular}{|c|c|c|c|c|}
\hline $\mathrm{T}_{\mathrm{f}}$ & $\mathrm{O} / \mathrm{L}$ fly box & $3 \mathrm{O} / \mathrm{L}$ & $\mathrm{S}_{\mathrm{f}}$ & 0.10 \\
\hline $\mathrm{U}_{\mathrm{f}}$ & $\begin{array}{l}\text { Tack fly box } \\
\text { end }\end{array}$ & $\mathrm{L} / \mathrm{S}$ & $\mathrm{T}_{\mathrm{f}}$ & 0.09 \\
\hline$V_{f}$ & $\begin{array}{l}\text { Attach fly } \\
\text { box to the } \\
\text { front panel }\end{array}$ & $\mathrm{L} / \mathrm{S}$ & $\mathrm{R}_{\mathrm{f}} \& \mathrm{U}_{\mathrm{f}}$ & 0.30 \\
\hline $\mathrm{W}_{\mathrm{f}}$ & $\begin{array}{l}\text { Tack waist } \\
\text { band on fly } \\
\text { box corner }\end{array}$ & $\mathrm{L} / \mathrm{S}$ & $\mathrm{V}_{\mathrm{f}}$ & 0.08 \\
\hline$X_{f}$ & Close zipper & $\mathrm{L} / \mathrm{S}$ & $\mathrm{W}_{\mathrm{f}}$ & 0.21 \\
\hline$Y_{f}$ & Tack crotch & $\mathrm{L} / \mathrm{S}$ & $\mathrm{X}_{\mathrm{f}}$ & 0.16 \\
\hline \multicolumn{4}{|c|}{ Total SMV } & 7.04 \\
\hline
\end{tabular}

Total number of Kanbans allocated to the front section was 7 and the total SMV of the front operation section is 7.04. Number of Kanban belongs to each operation was calculated based on the standard time of the operation. Number of Kanbans belongs to the operation $\mathrm{i}$ is calculated as,

(Standard time of the operation $i \times$

Number of Kanbans allocated to the section) / Total standard minute value of the operations belongs to the section

The calculated values of number of Kanbans for all operations were decimal values. The operations were combined and made groups to get approximate integer values for the number of Kanbans. When combining the operations, as much as possible, combined operations use the same parts and the same machine to minimize the handling times. Table II shows combined operations and the allocation of Kanbans of the front section.

Table- II: Number of Kanbans assigned to each operation and the combination of operations in the front section

\begin{tabular}{|c|c|c|c|c|c|c|}
\hline & & Operation & & & Numbe & f Kanban \\
\hline Input & Identity & Description & Machine & SMV & Operation & $\begin{array}{l}\text { Combined } \\
\text { operations }\end{array}$ \\
\hline $\begin{array}{l}\text { Cutting } \\
\text { section }\end{array}$ & $\mathrm{A}_{\mathrm{f}}$ & Facing attach on front pocket bag & $\mathrm{L} / \mathrm{S}$ & 0.82 & 0.8 & \\
\hline $\mathrm{A}_{\mathrm{f}}$ & $\mathrm{B}_{\mathrm{f}}$ & Close pocket bag & $4 \mathrm{O} / \mathrm{L}$ & 0.58 & 0.6 & \\
\hline $\mathrm{B}_{\mathrm{f}}$ & $\mathrm{C}_{\mathrm{f}}$ & Turn \& outline pocket bag & $\mathrm{L} / \mathrm{S}$ & 0.60 & 0.6 & 2.0 \\
\hline $\begin{array}{l}\text { Cutting } \\
\text { section }\end{array}$ & $\mathrm{D}_{\mathrm{f}}$ & Outline fly hem & $\mathrm{L} / \mathrm{S}$ & 0.10 & 0.1 & \\
\hline $\begin{array}{l}D_{\mathrm{f}} \& \\
\text { Stores }\end{array}$ & $\mathrm{E}_{\mathrm{f}}$ & Attach zipper to the fly & $\begin{array}{c}\mathrm{L} / \mathrm{S}, \\
\text { zipper foot }\end{array}$ & 0.40 & 0.4 & \\
\hline $\begin{array}{l}\text { Cutting } \\
\text { section }\end{array}$ & $\mathrm{F}_{\mathrm{f}}$ & $\mathrm{O} / \mathrm{L}$ front rises & $3 \mathrm{O} / \mathrm{L}$ & 0.22 & 0.2 & \\
\hline$E_{f} \& F_{f}$ & $\mathrm{G}_{\mathrm{f}}$ & Attach fly to front & $\mathrm{L} / \mathrm{S}$ & 0.26 & 0.3 & 1.0 \\
\hline $\begin{array}{l}\text { Cutting } \\
\text { section }\end{array}$ & $\mathrm{H}_{\mathrm{f}}$ & Tack waist band pieces together & $\mathrm{L} / \mathrm{S}$ & 0.24 & 0.2 & \\
\hline $\mathrm{H}_{\mathrm{f}}$ & $\mathrm{I}_{\mathrm{f}}$ & Sew waist band Kansai stitch & Kansai & 0.24 & 0.2 & \\
\hline $\mathrm{I}_{\mathrm{f}}$ & $\mathrm{J}_{\mathrm{f}}$ & Iron waist band hem & Iron & 0.30 & 0.3 & 1.0 \\
\hline
\end{tabular}


Kanban in Apparel Manufacturing: A Case Study

\begin{tabular}{|c|c|c|c|c|c|c|}
\hline \begin{tabular}{|l}
$\mathrm{J}_{\mathrm{f}} \&$ \\
Stores \\
\end{tabular} & $\mathrm{K}_{\mathrm{f}}$ & Tack labels on waist band & $\mathrm{L} / \mathrm{S}$ & 0.28 & 0.3 & \\
\hline $\mathrm{C}_{\mathrm{f}} \& \mathrm{G}_{\mathrm{f}}$ & $\mathrm{L}_{\mathrm{f}}$ & Pocket bag attach on front & $2 \mathrm{~L} / \mathrm{S}$ & 0.58 & 0.6 & \multirow[b]{3}{*}{1.1} \\
\hline $\mathrm{L}_{\mathrm{f}}$ & $\mathrm{M}_{\mathrm{f}}$ & Tack pocket bag on side \& waist & $\mathrm{L} / \mathrm{S}$ & 0.38 & 0.4 & \\
\hline $\mathrm{M}_{\mathrm{f}}$ & $\mathrm{N}_{\mathrm{f}}$ & Tack pocket mouth top & $\mathrm{L} / \mathrm{S}$ & 0.14 & 0.1 & \\
\hline$N_{f} \& K_{f}$ & $\mathrm{O}_{\mathrm{f}}$ & Attach WB to fly corner & $\mathrm{L} / \mathrm{S}$ & 0.21 & 0.2 & \multirow[b]{4}{*}{0.8} \\
\hline $\mathrm{O}_{\mathrm{f}}$ & $P_{f}$ & Turn WB corner of fly side & Table & 0.10 & 0.1 & \\
\hline $\mathrm{P}_{\mathrm{f}}$ & $\mathrm{Q}_{\mathrm{f}}$ & Sew fly edge stitch & $\mathrm{L} / \mathrm{S}$ & 0.11 & 0.1 & \\
\hline $\mathrm{Q}_{\mathrm{f}}$ & $\mathrm{R}_{\mathrm{f}}$ & Sew fly J stitch & $\mathrm{L} / \mathrm{S}$ & 0.32 & 0.3 & \\
\hline $\begin{array}{l}\text { Cutting } \\
\text { section }\end{array}$ & $S_{\mathrm{f}}$ & Tack and turn fly box & $\mathrm{L} / \mathrm{S}$ & 0.22 & 0.2 & \multirow{7}{*}{1.2} \\
\hline $\mathrm{S}_{\mathrm{f}}$ & $\mathrm{T}_{\mathrm{f}}$ & O/L fly box & $3 \mathrm{O} / \mathrm{L}$ & 0.10 & 0.1 & \\
\hline $\mathrm{T}_{\mathrm{f}}$ & $\mathrm{U}_{\mathrm{f}}$ & Tack fly box end & $\mathrm{L} / \mathrm{S}$ & 0.09 & 0.1 & \\
\hline $\mathrm{R}_{\mathrm{f}} \& \mathrm{U}_{\mathrm{f}}$ & $V_{f}$ & Attach fly box to the front panel & $\mathrm{L} / \mathrm{S}$ & 0.30 & 0.3 & \\
\hline $\mathrm{V}_{\mathrm{f}}$ & $\mathrm{W}_{\mathrm{f}}$ & Tack waist band on fly box corner & $\mathrm{L} / \mathrm{S}$ & 0.08 & 0.1 & \\
\hline $\mathrm{W}_{\mathrm{f}}$ & $\mathrm{X}_{\mathrm{f}}$ & Close zipper & $\mathrm{L} / \mathrm{S}$ & 0.21 & 0.2 & \\
\hline $\mathrm{X}_{\mathrm{f}}$ & $\mathrm{Y}_{\mathrm{f}}$ & Tack crotch & $\mathrm{L} / \mathrm{S}$ & 0.16 & 0.2 & \\
\hline
\end{tabular}

Thereafter operators were allocated to each operation. As the total number of operators allocated to the line was 35 and the total SMV was 33.61, on average, each operator is assigned 0.96 minutes of work approximately. Table III shows the allocated operations to each operator/s and the number of Kanbans for their operations. The combined operations are named as groups.

Table- III: Number of operators and the Kanban assigned to the front operation section

\begin{tabular}{|c|c|c|c|c|}
\hline 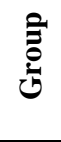 & 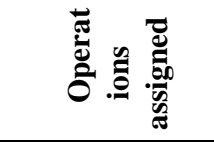 & 总比兽 & $\stackrel{\widetilde{\sigma}}{0} \sum_{\infty}^{2}$ & 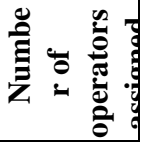 \\
\hline $\mathrm{G}_{1}$ & $\mathrm{~A}_{\mathrm{f}}, \mathrm{B}_{\mathrm{f}}, \mathrm{C}_{\mathrm{f}}$ & $2-\left(\mathrm{K}_{1}, \mathrm{~K} 2\right)$ & 2.00 & 2 \\
\hline $\mathrm{G}_{2}$ & $\mathrm{D}_{\mathrm{f}}, \mathrm{E}_{\mathrm{f}}, \mathrm{F}_{\mathrm{f},}, \mathrm{G}_{\mathrm{f}}$ & 1- (K3) & 0.98 & 1 \\
\hline $\mathrm{G}_{3}$ & $\mathrm{H}_{\mathrm{f}}, \mathrm{I}_{\mathrm{f}}, \mathrm{J}_{\mathrm{f}, \mathrm{,}} \mathrm{K}_{\mathrm{f}}$ & 1- (K4) & 1.06 & 1 \\
\hline G4 & $\mathrm{Lf}_{\mathrm{f}} \mathrm{M}_{\mathrm{f}}, \mathrm{N}_{\mathrm{f}}$ & 1- (K5) & 1.10 & 1 \\
\hline $\mathrm{G}_{5}$ & $\mathrm{O}_{\mathrm{f}}, \mathrm{P}_{\mathrm{f}}, \mathrm{Q}_{\mathrm{f},}, \mathrm{R}_{\mathrm{f}}$ & 1- (K6) & 0.74 & 1 \\
\hline $\mathrm{G}_{6}$ & $\begin{array}{l}T_{f}, U_{f}, V_{f,}, W_{f}, \\
X_{f}, Y_{f}\end{array}$ & 1- (K7) & 1.16 & 1 \\
\hline
\end{tabular}

As per the SMV allocations for the operators, the time of the operator assigned to the group 5 was 0.74 minutes and for group 6, it was 1.16 minutes. The operator at the 5th group has less time of work, she can help the operator at the group 6.

Figure 2 shows the number of Kanban allocated to each group and the flow of the WIPs in the front operation section. The operations are shown in the circles. The material flow direction is shown by arrows. The material handler of the line, who carries the cut bundles from the cutting section, puts the garment parts (4 from each part) required to perform the respective operations into boxes. Cards are prepared indicating the card number, style number, group number and the parts included as shown in the Figure 1. A small removable sticker is fixed by the material handler on the card by indicating the piece numbers of the order. As an example operations Af, $\mathrm{Bf} \& \mathrm{Cf}$ are carried out at the operation group G1 and the number of Kanbans allocated is 2, and they are named as K1 \& K2. The card is attached to the box. G1 collects the box from the material handler and completes the operations. As the system is a pull system the materials are pulled from the downstream operations. G4 collects the parts in the box K1, as G4 is the internal customer of G1 and put them to the box K4. At the same time the part number sticker is pasted in $\mathrm{K} 4$, as the part number sticker of $\mathrm{K} 4$ is already taken by the G5. Then G1 collects the next bundle from the material handler and put into $\mathrm{K} 1$ and, as the part number sticker is taken from the G4 the respective part number is taken and pasted. When a there are 2 internal customers, the group will collect 2 stickers of part numbers from 2 groups. The Kanban card for them are designed to paste both stickers to make sure the collection of parts. All the material transports should happen at the same time at 3.84 minutes intervals.

\begin{tabular}{|c|c|}
\hline \multicolumn{2}{|c|}{ Style: ABC - Order 2} \\
\hline \multirow[b]{2}{*}{11} & Quantity: 4 \\
\hline & Piece nos. 105-108 \\
\hline \multirow{4}{*}{$G_{1}$} & Parts included \\
\hline & Front panels \\
\hline & Front pocket bag \\
\hline & Front pocket facing \\
\hline
\end{tabular}

Fig. 1. Sample of a Kanban card

Published By:

Blue Eyes Intelligence Engineering and Sciences Publication 


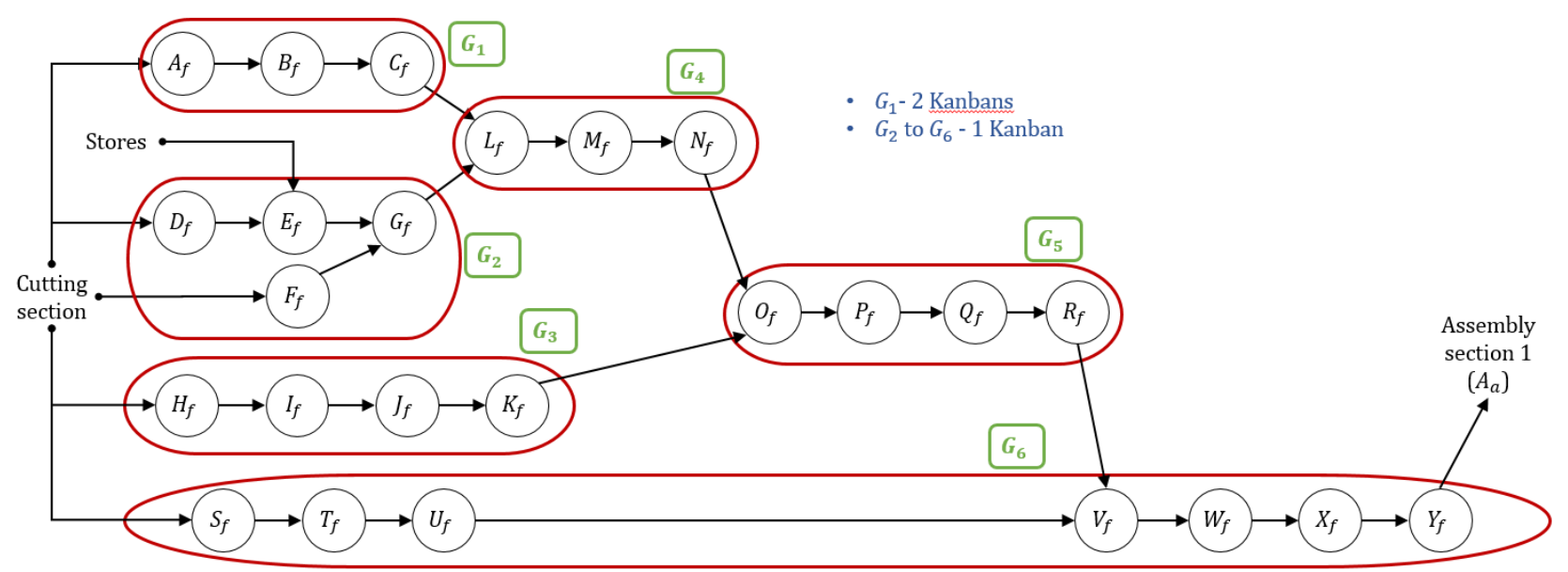

Fig. 2. Flow of the materials in the Front operation section

Same procedure was repeated for the other sections: back operations, assembly section 1 and assembly section 2 . Table IV, Table VI \& the Table VIII show the number of Kanbans and operation combinations for the back section, assemble 1 section and assemble 2 sections respectively. Table V, Table
VII \& Table IX show the operator allocations for those sections respectively. Figure 3, Figure 4 and Figure 5 show the material flow and the group allocations of the back section, assemble 1 section and assemble 2 sections respectively.

Table- IV: Number of Kanban assigned to each operation and the combination of operations in the back section

\begin{tabular}{|c|c|c|c|c|c|c|}
\hline \multicolumn{3}{|r|}{ Operation } & \multirow{2}{*}{ Machine } & \multirow{2}{*}{ SMV } & \multicolumn{2}{|c|}{ Number of Kanban } \\
\hline Input & Identity & Description & & & Operation & $\begin{array}{l}\text { Combined } \\
\text { operations }\end{array}$ \\
\hline $\begin{array}{l}\text { Cutting } \\
\text { section }\end{array}$ & $\mathrm{B}_{\mathrm{b}}$ & Iron welt facing & Iron table & 0.90 & 0.9 & 0.9 \\
\hline $\begin{array}{l}\text { Cutting } \\
\text { section }\end{array}$ & $\mathrm{C}_{\mathrm{b}}$ & $\begin{array}{l}\text { Iron back \& side pocket under } \\
\text { patches }\end{array}$ & Iron table & 1.00 & 1.1 & 1.1 \\
\hline $\begin{array}{l}\text { Cutting } \\
\text { section }\end{array}$ & $\mathrm{D}_{\mathrm{b}}$ & Mark back under patch placement & Table & 0.30 & 0.3 & 1.0 \\
\hline $\mathrm{D}_{\mathrm{b}}$ & $\mathrm{E}_{\mathrm{b}}$ & $\begin{array}{l}\text { Sew back darts, Tack back darts on } \\
\text { the waist }\end{array}$ & $\mathrm{L} / \mathrm{S}$ & 0.32 & 0.3 & \\
\hline $\mathrm{E}_{\mathrm{b}}$ & $\mathrm{F}_{\mathrm{b}}$ & Out line back darts. & $\mathrm{L} / \mathrm{S}$ & 0.33 & 0.4 & \\
\hline $\mathrm{C}_{\mathrm{b}} \& \mathrm{~F}_{\mathrm{b}}$ & $\mathrm{G}_{\mathrm{b}}$ & Attach back under patch & Velcro m/c & 0.62 & 0.7 & 1.1 \\
\hline $\begin{array}{l}\text { Cutting } \\
\text { section }\end{array}$ & $\mathrm{H}_{\mathrm{b}}$ & Facing attach on back pocket bag. & $\mathrm{L} / \mathrm{S}$ & 0.36 & 0.4 & \\
\hline $\begin{array}{l}\mathrm{Bb}, \mathrm{G}_{\mathrm{b}} \\
\& \mathrm{H}_{\mathrm{b}}\end{array}$ & $\mathrm{I}_{\mathrm{b}}$ & Make back welt & welt & 0.95 & 1.0 & 1.0 \\
\hline $\mathrm{I}_{\mathrm{b}}$ & $\mathrm{J}_{\mathrm{b}}$ & Tack welt pocket ends & $\mathrm{L} / \mathrm{S}$ & 0.58 & 0.6 & 1.0 \\
\hline $\mathrm{J}_{\mathrm{b}}$ & $\mathrm{K}_{\mathrm{b}}$ & Close welt pocket bag facing & $\mathrm{L} / \mathrm{S}$ & 0.36 & 0.4 & \\
\hline $\mathrm{K}_{\mathrm{b}}$ & $\mathrm{L}_{\mathrm{b}}$ & Close back pocket bag & $\mathrm{L} / \mathrm{S}$ & 0.92 & 1.0 & 1.0 \\
\hline $\mathrm{L}_{\mathrm{b}}$ & $\mathrm{M}_{\mathrm{b}}$ & Turn \& outline back pocket bag & $\mathrm{L} / \mathrm{S}$ & 0.95 & 1.0 & 1.0 \\
\hline
\end{tabular}


Kanban in Apparel Manufacturing: A Case Study

\begin{tabular}{|c|c|c|c|c|c|c|}
\hline $\begin{array}{l}\text { Cutting } \\
\text { section }\end{array}$ & $A_{b}$ & Iron back pocket flaps & Iron table & 0.20 & 0.2 & \multirow[t]{3}{*}{1.1} \\
\hline $\mathrm{A}_{\mathrm{b}}$ & $\mathrm{N}_{\mathrm{b}}$ & Attach snaps on back under flap & $\begin{array}{l}\text { Snap button } \\
\mathrm{m} / \mathrm{c}\end{array}$ & 0.40 & 0.4 & \\
\hline $\mathrm{N}_{\mathrm{b}}$ & $\mathrm{O}_{\mathrm{b}}$ & Outline flaps (back) & $\mathrm{L} / \mathrm{S}$ & 0.52 & 0.5 & \\
\hline $\mathrm{O}_{\mathrm{b}}$ & $\mathrm{P}_{\mathrm{b}}$ & Tack welt pocket ends & BT & 0.62 & 0.7 & \multirow[t]{2}{*}{1.0} \\
\hline $\mathrm{P}_{\mathrm{b}}$ & $\mathrm{Qb}_{\mathrm{b}}$ & Iron pocket facing & Iron & 0.30 & 0.3 & \\
\hline $\mathrm{Q}_{\mathrm{b} \&} \mathrm{M}_{\mathrm{b}}$ & $\mathrm{R}_{\mathrm{b}}$ & $\begin{array}{l}\text { Sew welt top mouth outline with } \\
\text { flaps }\end{array}$ & $\mathrm{L} / \mathrm{S}$ & 0.96 & 1.0 & 1.0 \\
\hline
\end{tabular}

Table- V: Number of operators and the Kanban assigned to the back operation section

\begin{tabular}{|c|c|c|c|c|}
\hline 苞 气 & 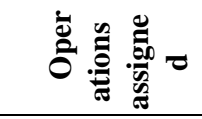 & 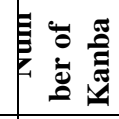 & $\sum_{n}^{ \pm}$ & 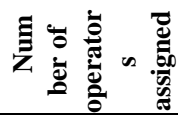 \\
\hline $\mathrm{G}_{7}$ & $\mathrm{~B}_{\mathrm{b}}$ & 1 & 0.90 & 1 \\
\hline $\mathrm{G}_{8}$ & $\mathrm{Cb}_{\mathrm{b}}$ & 1 & 1.00 & 1 \\
\hline G9 & $\mathrm{Db}_{\mathrm{b}}, \mathrm{Eb}_{\mathrm{b}}, \mathrm{F}_{\mathrm{b}}$ & 1 & 0.95 & 1 \\
\hline $\mathrm{G}_{10}$ & $\mathrm{G}_{\mathrm{b}}, \mathrm{H}_{\mathrm{b}}$ & 1 & 0.98 & 1 \\
\hline $\mathrm{G}_{11}$ & $\mathrm{I}_{\mathrm{b}}$ & 1 & 0.95 & 1 \\
\hline $\mathrm{G}_{12}$ & $\mathrm{~J}_{\mathrm{b}}, \mathrm{K}_{\mathrm{b}}$ & 1 & 0.94 & 1 \\
\hline $\mathrm{G}_{13}$ & $\mathrm{Lb}$ & 1 & 0.92 & 1 \\
\hline $\mathrm{G}_{14}$ & $\mathrm{Mb}$ & 1 & 0.95 & 1 \\
\hline $\mathrm{G}_{15}$ & $\mathrm{~A}_{\mathrm{b}}, \mathrm{N}_{\mathrm{b}}, \mathrm{O}_{\mathrm{b}}$ & 1 & 1.12 & 1 \\
\hline
\end{tabular}

\begin{tabular}{|c|l|r|r|c|}
\hline $\mathrm{G}_{16}$ & $\mathrm{P}_{\mathrm{b}}, \mathrm{Q}_{\mathrm{b}}$ & 1 & 0.92 & 1 \\
\hline $\mathrm{G}_{17}$ & $\mathrm{R}_{\mathrm{b}}$ & 1 & 0.96 & 1 \\
\hline & Total & 1 & 9.09 & 11 \\
& & 1 & & \\
\hline
\end{tabular}

As the operator's time at G15 is comparatively high and in G13 is comparatively less, the operator at G13 was asked instructed to help the operator G15 to complete the production. In addition, the operator at G7 was instructed to help the operator at G8 to maintain the time balancing. Figure 3 shows the flow of the materials in the back operation section.

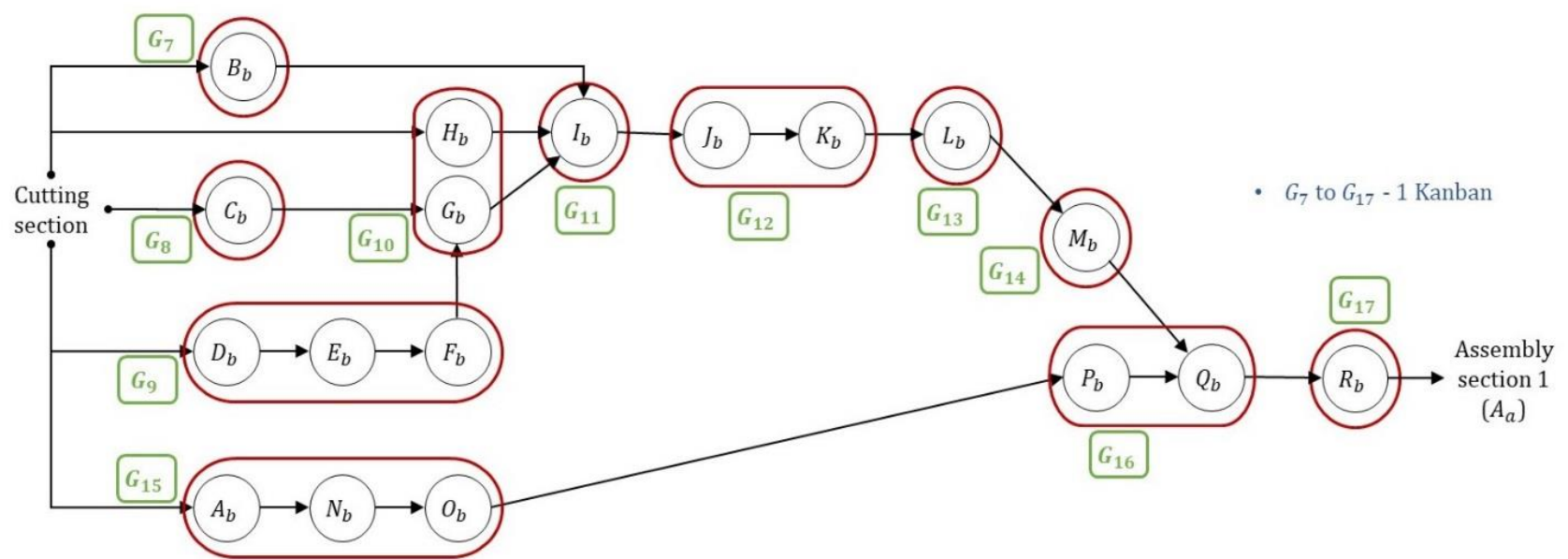

Fig. 3. Flow of materials in the back operation section

Table- VI: Number of Kanban assigned to each operation and the combination of operations in the assembly section 1

\begin{tabular}{|c|c|c|c|c|c|c|}
\hline \multicolumn{3}{|r|}{ Operation } & \multirow{2}{*}{ Machine } & \multirow{2}{*}{$\begin{array}{l}\text { SM } \\
\text { V }\end{array}$} & \multicolumn{2}{|c|}{ Number of Kanban } \\
\hline Input & Identity & Description & & & Operation & $\begin{array}{l}\text { Combined } \\
\text { operations }\end{array}$ \\
\hline $\mathrm{Y}_{\mathrm{f}} \& \mathrm{~S}_{\mathrm{b}}$ & $\mathrm{A}_{\mathrm{a}}$ & Sew side seam & $5 \mathrm{O} / \mathrm{L}$ & 0.55 & 0.6 & \\
\hline $\mathrm{A}_{\mathrm{a}}$ & $\mathrm{B}_{\mathrm{a}}$ & Out line side seam & 2 Chain & 0.86 & 0.9 & \\
\hline $\mathrm{B}_{\mathrm{a}}$ & $\mathrm{C}_{\mathrm{a}}$ & Mark under patch placement & Table & 0.40 & 0.4 & 2.0 \\
\hline $\begin{array}{l}\text { Cutting } \\
\text { section }\end{array}$ & $\mathrm{D}_{\mathrm{a}}$ & Iron flaps & Iron & 0.65 & 0.7 & 2.0 \\
\hline
\end{tabular}




\begin{tabular}{|c|c|c|c|c|c|c|}
\hline $\mathrm{D}_{\mathrm{a}}$ & $\mathrm{E}_{\mathrm{a}}$ & Attach snaps on flap under part & $\begin{array}{c}\text { Snap } \\
\text { machine }\end{array}$ & 0.40 & 0.4 & \multirow[b]{4}{*}{1.7} \\
\hline $\mathrm{E}_{\mathrm{a}}$ & $\mathrm{F}_{\mathrm{a}}$ & Outline flaps (front) & $\mathrm{L} / \mathrm{S}$ & 0.76 & 0.8 & \\
\hline $\begin{array}{l}\text { Cutting } \\
\text { section }\end{array}$ & $\mathrm{G}_{\mathrm{a}}$ & Iron side pocket under patch & Iron & 0.80 & 0.9 & \\
\hline $\mathrm{G}_{\mathrm{a}, \mathrm{C}_{\mathrm{a}}}$ & $\mathrm{H}_{\mathrm{a}}$ & Attach underside patch & $\mathrm{L} / \mathrm{S}$ & 0.75 & 0.8 & \\
\hline $\begin{array}{l}\text { Cutting } \\
\text { section }\end{array}$ & $\mathrm{I}_{\mathrm{a}}$ & Sew front pocket pleats & $\mathrm{L} / \mathrm{S}$ & 0.33 & 0.4 & \multirow[b]{2}{*}{0.9} \\
\hline $\mathrm{I}_{\mathrm{a}}$ & $\mathrm{J}_{\mathrm{a}}$ & Sew front pocket hem & $\mathrm{L} / \mathrm{S}$ & 0.45 & 0.5 & \\
\hline $\mathrm{H}_{\mathrm{a}} \& \mathrm{~J}_{\mathrm{a}}$ & $\mathrm{K}_{\mathrm{a}}$ & Attach side pockets & $\mathrm{L} / \mathrm{S}$ & 0.90 & 1.0 & 1.0 \\
\hline $\begin{array}{c}F_{\text {a }} \& \mathrm{~K} \\
\mathrm{a}\end{array}$ & $\mathrm{L}_{\mathrm{a}}$ & Attach side flaps & $\mathrm{L} / \mathrm{S}$ & 0.58 & 0.6 & \multirow[b]{3}{*}{1.4} \\
\hline $\mathrm{L}_{\mathrm{a}}$ & $\mathrm{M}_{\mathrm{a}}$ & Sew in seams & $5 \mathrm{O} / \mathrm{L}$ & 0.30 & 0.3 & \\
\hline $\mathrm{M}_{\mathrm{a}}$ & $\mathrm{N}_{\mathrm{a}}$ & Sew front $\&$ back rises & $5 \mathrm{O} / \mathrm{L}$ & 0.39 & 0.4 & \\
\hline $\mathrm{N}_{\mathrm{a}}$ & $\mathrm{O}_{\mathrm{a}}$ & Out line in seam & $\begin{array}{l}\text { Feed of the } \\
\text { arm }\end{array}$ & 0.32 & 0.4 & \multirow[b]{2}{*}{1.1} \\
\hline $\mathrm{O}_{\mathrm{a}}$ & $\mathrm{P}_{\mathrm{a}}$ & Out line front $\&$ back rises & $2 \mathrm{~L} / \mathrm{S}$ & 0.65 & 0.7 & \\
\hline
\end{tabular}

Table- VII: Number of operators and the Kanban assigned to the Assembly 1 section

\begin{tabular}{|c|c|c|c|c|}
\hline ○̊ & 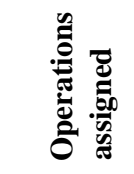 & 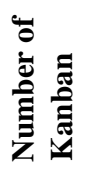 & $\frac{\sum_{\infty}^{Z}}{\underbrace{0}_{0}}$ & 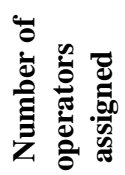 \\
\hline${ }_{18} \mathrm{G}$ & ${ }_{C_{a}}{ }^{A_{a}, B_{a},}$ & 2 & 1.81 & 2 \\
\hline${ }_{19} \mathrm{G}$ & $\begin{array}{l}\mathrm{D}_{\mathrm{a}}, \mathrm{E}_{\mathrm{a}}, \\
\end{array}$ & 2 & 1.81 & 2 \\
\hline${ }_{20} \mathrm{G}$ & $\mathrm{G}_{\mathrm{a}}, \mathrm{H}_{\mathrm{a}}$ & 2 & 1.55 & 2 \\
\hline${ }_{21} \mathrm{G}$ & $\mathrm{I}_{\mathrm{a}}, \mathrm{J}_{\mathrm{a}}$ & 1 & 0.78 & 1 \\
\hline
\end{tabular}

\begin{tabular}{|r|c|c|c|c|}
\hline $\begin{array}{c}\mathrm{G} \\
22\end{array}$ & $\mathrm{~K}_{\mathrm{a}}$ & 1 & 0.90 & 1 \\
\hline $\begin{array}{c}\mathrm{G} \\
23\end{array}$ & $\begin{array}{c}\mathrm{La}, \mathrm{M}_{\mathrm{a}}, \\
\mathrm{N}^{\mathrm{a}}\end{array}$ & 1 & 1.27 & 1 \\
\hline $\begin{array}{c}\mathrm{G} \\
24\end{array}$ & $\mathrm{Oa}, \mathrm{Pa}$ & 1 & 0.97 & 1 \\
\hline
\end{tabular}

At $\mathrm{G}_{20} \& \mathrm{G}_{21}$, the allocated operators have less time than the other operators and the operator assigned to $\mathrm{G}_{23}$ has more work than the average. Therefore, the operators in the $\mathrm{G}_{20}$ \& $\mathrm{G}_{21}$ were instructed to help the operator at $\mathrm{G}_{23}$. Figure 4 shows the flow of the materials in the Assembly section 1.

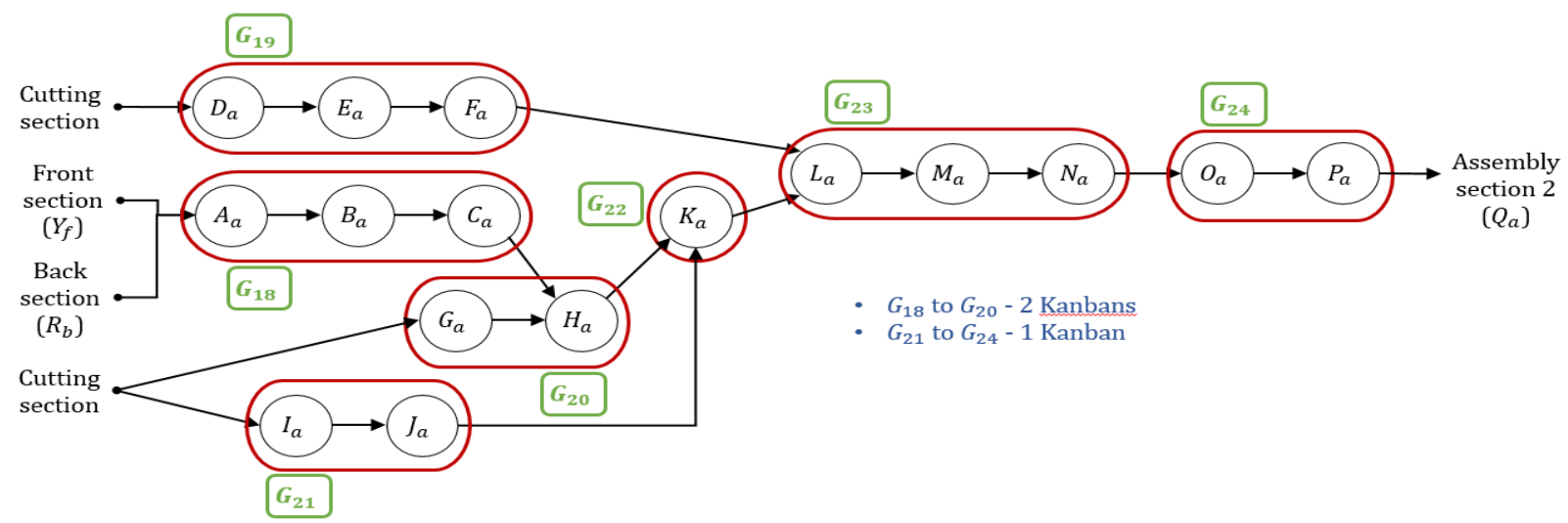

Fig. 4. Flow of materials in the Assembly section 1 
Table- VIII: Number of Kanban assigned to each operation and the combination of operations in the assembly 2 section

\begin{tabular}{|c|c|c|c|c|c|c|}
\hline \multicolumn{3}{|c|}{ Operation } & \multirow{2}{*}{ Machine } & \multirow{2}{*}{ SMV } & \multicolumn{2}{|c|}{ Number of Kanban } \\
\hline Input & Identity & Description & & & Operation & $\begin{array}{l}\text { Combined } \\
\text { operations }\end{array}$ \\
\hline $\mathrm{P}_{\mathrm{a}}$ & $\mathrm{Q}_{\mathrm{a}}$ & Tack loops on WB & $\mathrm{L} / \mathrm{S}$ & 0.65 & 0.7 & \\
\hline $\mathrm{Q}_{\mathrm{a}}$ & $\mathrm{R}_{\mathrm{a}}$ & Attach waist band & $\mathrm{L} / \mathrm{S}$ & 0.72 & 0.7 & 2.0 \\
\hline $\mathrm{R}_{\mathrm{a}}$ & $\mathrm{S}_{\mathrm{a}}$ & Sew waist band top edge out line & $\mathrm{L} / \mathrm{S}$ & 0.58 & 0.6 & \\
\hline $\mathrm{S}_{\mathrm{a}}$ & $\mathrm{T}_{\mathrm{a}}$ & Close waist band & $2 \mathrm{~L} / \mathrm{S}$ & 0.94 & 1.0 & 1.0 \\
\hline $\mathrm{T}_{\mathrm{a}}$ & $\mathrm{U}_{\mathrm{a}}$ & Bar tack garment & BT & 1.00 & 1.0 & 1.0 \\
\hline $\mathrm{U}_{\mathrm{a}}$ & $\mathrm{V}_{\mathrm{a}}$ & Sew Reese hole waist band & $\begin{array}{c}\text { Reese } \\
\text { button hole }\end{array}$ & 0.20 & 0.2 & \\
\hline $\begin{array}{l}\mathrm{V}_{\mathrm{a}} \& \\
\text { Stores }\end{array}$ & $\mathrm{W}_{\mathrm{a}}$ & Mark \& attach waist band button & $\begin{array}{c}\text { Button } \\
\text { Attach }\end{array}$ & 0.20 & 0.2 & 1.1 \\
\hline $\mathrm{W}_{\mathrm{a}}$ & $X_{a}$ & Sew bottom hem & $2 \mathrm{~L} / \mathrm{S}$ & 0.70 & 0.7 & \\
\hline $\mathrm{X}_{\mathrm{a}}$ & $\mathrm{Y}_{\mathrm{a}}$ & Bar tack loops & $\mathrm{BT}$ & 1.00 & 1.00 & 1.0 \\
\hline $\mathrm{Ya}_{\mathrm{a}}$ & $\mathrm{Z}_{\mathrm{a}}$ & Attach snap buttons & Snap & 0.90 & 0.93 & 0.9 \\
\hline
\end{tabular}

Table- IX: Number of operators and the Kanban assigned to the assembly 2 section

\begin{tabular}{|c|c|c|c|c|}
\hline 을 & 胥 & 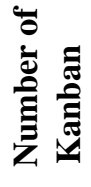 & 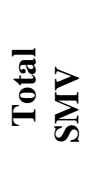 & 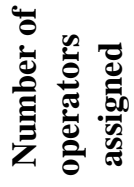 \\
\hline $\mathrm{G}_{25}$ & $\mathrm{Q}_{\mathrm{a}}, \mathrm{R}_{\mathrm{a}}, \mathrm{S}_{\mathrm{a}}$ & 2 & 1.81 & 2 \\
\hline $\mathrm{G}_{26}$ & $\mathrm{~T}_{\mathrm{a}}$ & 1 & 0.94 & 1 \\
\hline
\end{tabular}

\begin{tabular}{|c|l|c|c|c|}
\hline $\mathrm{G}_{27}$ & $\mathrm{U}_{\mathrm{a}}$ & 1 & 1.00 & 1 \\
\hline $\mathrm{G}_{28}$ & $\mathrm{~V}_{\mathrm{a},} \mathrm{W}_{\mathrm{a}} \mathrm{X}_{\mathrm{a}}$ & 1 & 1.1 & 1 \\
\hline $\mathrm{G}_{29}$ & $\mathrm{Y}_{\mathrm{a}}$ & 1 & 1.0 & 1 \\
\hline $\mathrm{G}_{33}$ & $\mathrm{Z}_{\mathrm{a}}$ & 1 & 0.9 & 1 \\
\hline
\end{tabular}

In the assembly section 2 operator at G26 was instructed to help the operator at G28. Figure 5 illustrates the movements of the Kanbans in the Assembly section 2.

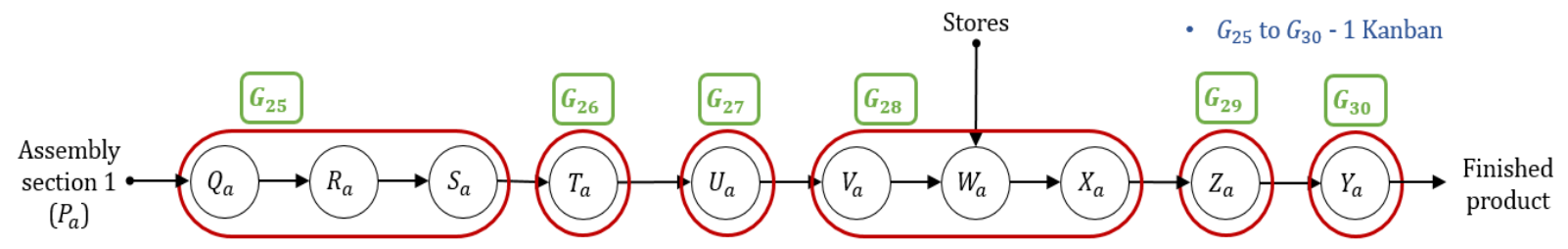

Fig. 5: Flow of materials in the Assembly section 2

\section{RESULTS AND DISCUSSION}

One week after the implementation of the Kanban system, the number of Kanbans at the allocated places were counted hourly for 2 weeks. At every observation, the number of Kanbans recorded were similar to the Kanban allocations of each group and the total number of Kanbans were 35 at all the time. It was instructed to stop the line quickly when any critical problems happened. Accordingly, the line was stopped at 38 such incidents during the 2 weeks period-until the problem is solved. The reasons for the stoppages were quality problems (20 times), machine breakdowns (12 times) and input delay from the cutting section (4 times) and the stores (2 times). The total time lost during these 38 stoppages was 208 minutes. Though, some lean manufacturing techniques have been implemented, the factory need to further improve them. During this period of 2 weeks, average production output was 518 pieces - the minimum and maximum production per day were 492 pieces and 526 pieces respectively. The production output has increased by $22 \%$.

According to the lighting arrangement of the factory the line layout was limited to 2 straight lines. Therefore some materials were moved to some distance as per the material flow.

Published By:

Blue Eyes Intelligence Engineering and Sciences Publication 
Here the lighting and the line setup should organize to minimize the material movements. By eliminating the above mentioned drawbacks the factory can maximize the gain of the Kanban system.

\section{CONCLUSION}

The pull system incorporated with Kanban system is a proved to be highly effective in manufacturing industries. This research implemented a Kanban system in a highly labor-intensive apparel manufacturing Industry. Despite several line stoppages due to various problems during the observed time of 2 weeks, the production output has been increased by 22\%. Moreover, the correct number of Kanban cards at the Kanban collecting points is an indication of the effective implementation of the Kanban system.

The selected factory had implemented some of the major lean manufacturing tools and techniques: setup reduction, TPM and TQM are among them. Having implemented these tools and techniques would be a reason for effective implementation of the Kanban system. If the machines breakdowns were high and if the quality issues were high, the Kanban cards would not flow as expected. Number of Kanban card at the collecting points together with the improved production output is an indirect indication of the success of the other tools. As indicated by the skill matrix of the operators, the factory has a highly trained work force. Highly trained work force, implementation of major lean manufacturing tools and techniques are essential components for successful implementation of a Kanban system.

\section{REFERENCES}

1. W. J. Hopp and Spearman (2004), Pull or Not to Pull, Manufacturing \& Service Operations Management, 2004 Vol. 6, No. 2, pp. 133-148

2. N. Gopalakrishnan, Simplified Lean Manufacture- Elements, Rules, Tools \& Implementation, PHI Learning private limited, New Delhi-110001, (2012), pp 125-126

3. M. P. Groover, Automation, Production Systems and Computer integrated Manufacturing, Published by Pearson Education Inc., $5^{\text {th }}$ Edition, 2010, ISBN-978-81-203-3418-2, pp 775

4. M. M. Magana, O. T. Everardo, C. C. Wilson and J. L. G. Alcaraz, Impact of the Planning from the Kanban System on the Company's Operating Benefits, Sustainability, 2018, Volume 10, Issue 7

5. Y. Hirakawa, Performance of a multistage hybrid push/ pull production control system, International Journal of Production Economics, (1996), Volume 44, Issues 1-2, pp 129-135

6. J. Heizer and B. Render, Lean Manufacturing Case Study with Kanban System, Journal of Procedia Economics and Finance, 2005, $7^{\text {th }}$ edition,. pp 174-180

7. T. Ohno, Toyota Production System: Beyond Large Scale Production, Productivity Press, Cambridge, Mass, 1988

8. Y. Sugimori, K. Kusunoki, F. Cho and S. Uchikawa S. Toyota Production system Materialization of Just-In-Time and respect for Human system, The International Journal of Production Research, (2007), 15:6, 553-564, ISSN: 0020-7543

9. M. Shahil, Implications of Just-In-Time systems of Toyota- A case study, The final report produce for the Degree of Master of Innovation \& Operations Management, 2017, pages 35-37

10. H. W. Harahap, M. F. Marif and Y. Arkeman, Design \& Implementation to reduce the finished good inventory, International Journal of Science \& Research, 2018, Volume 7, Issue 1

11. N. B. Adnana, A. B. Jaffar, N. B. Yusoff and N. H. B. A. Halim, Implementation of Just in Time Production through Kanban System, International Knowledge Sharing Platform, 2013, Volume 3, No.6

12. N. A. A. Rahman, S.M. Sharif and M. M. Esa, Lean manufacturing case study with Kanban system implementation. Procedia Econ. Finance, (2013), No.7, pp 174-180.

13. M. D. Al-Tahat, Optimizing of work in progress (WIP) in Kanban controlled production lines, Dirasat Engineering Sciences, (2005), Volume 32, No. 2, 123-132

14. Rajat, L. B. Wakode and R. P. Talmale, Overview on Kanban Methodology and its implementation, International Journal for
Scientific Research \& Development, (2015), Volume 3, Issue 02, ISSN (online) 2321-0613.

15. N. Singh, S. K. Hung and D. Meloche, "The Development of a Kanban System: A Case Study", International Journal of Operations \& Production Management, (1990), Vol. 10 No. 7, pp. 28-36.

16. N. B. Adnana, A. B. Jaffar, N. B. Yusoff and N. H. B. A. Halim, The effect of Kanbans in Just in Time Production system to Manufacturing Performance, Applied Mechanics and Materials, 2013, Vol. 315, Page 645-649

17. Ali, M. Khadem and N. Santini, Kanban Supplier System as a Standardization Method and WIP Reduction, Proceedings of the 2010 International Conference on Industrial Engineering and Operations Management, Dhaka, Bangladesh, January 9-10,

18. M. Yousefi, I. Seyed, H. Hosseinioun and I.F. Taghikhah, Determining Optimum Number of Kanbans for Workstations in a Kanban-based Manufacturing Line using Discrete-Event Simulation: A Case Study; International Conference on Industrial Engineering and Operations Management Istanbul, (2012), Turkey, July 3-6

19. J. M. Association, Kanban Just-in Time at Toyota: Management Begins at the Workplace; CRC Press: Boca Raton, FL, USA, 1986 ISBN 9780915299485

20. J. Linck and S. David, The Importance of Takt Time in Manufacturing System Design, International Automotive Manufacturing Conference and Exposition Detroit, Michigan May 11-13, 1999

\section{AUTHORS PROFILE}

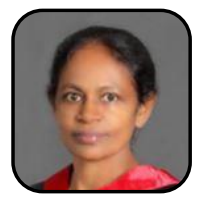

RMVS Ratnayake, is currently serving as a Senior Lecturer in the Department of Textile and Clothing Technology, Faculty of Engineering, University of Moratuwa. She has obtained a degree in B.Sc. Engineering specializing the Production Engineering from the Faculty of Engineering, University of Peradeniya, Sri Lanka and a Post Graduate diploma in Operational Research and a M.Phil. Degree in Lean Manufacturing from the University of Moratuwa, Sri Lanka. She has worked in a reputed Apparel factory in Sri Lanka as a Production Engineer for nearly 5 years, just after obtaining the first degree.

RMVS Ratnayake is a Charted Engineer and a member of the Institute of Engineers Sri Lanka and a life member of Applied Statistics Association, Sri Lanka. She has supervised several post graduate researches and currently supervising 2 post graduate research projects. She is authorized for more than 15 journal papers and about 10 conference papers. She renders her service as a reviewer to many international reputed journals. She is working as a consultant to the Manufacturing industry in Sri Lanka and have involved in many consultancy projects.

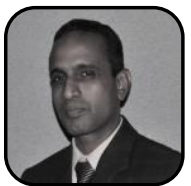

WDG Lanarolle, is a senior lecturer of the Department of Textile \& Apparel Engineering of the University of Moratuwa, Sri Lanka. He received the B.Sc. (Eng.) degree in Textile Technology from the University of Moratuwa and $\mathrm{PhD}$ in Knitting Technology from the Manchester University UK. His areas of expertise are knitting technology and process improvement. He has published 18 journal papers and presented papers in international conferences. He is working as a consultant to the textile industry in Sri Lanka and have involved in many consultancy projects.

WDG Lanarolle is a Charted Engineer and a member of the Institute of Engineers Sri Lanka. He has supervised several post graduate researches and currently supervising 2 post graduate research projects.

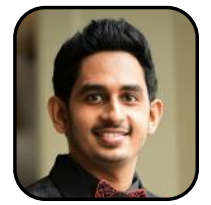

RMDT Ratnayake, received his B.Sc. in Engineering and M.Eng. degrees in the field of mechatronics engineering from the Asian Institute of Thailand. While completing his first degree, he has worked as a design engineer in manufacturing and automation industry. After obtaining his masters, he has served as a R\&D engineer in the field of AI while serving as a junior lecturer in the field of computer science at Siam University Bangkok. Key expertise of him includes control systems engineering, robotic systems design and development, computer aided design and computer aided manufacturing, industrial automation, and artificial intelligence. His publications comprise of work on experimentation of linear and nonlinear control theory.

Published By:

Blue Eyes Intelligence Engineering and Sciences Publication 9 (C) Copyright: All rights reserved.

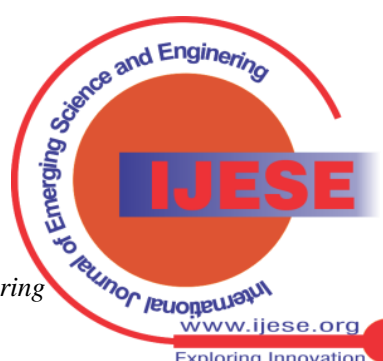

